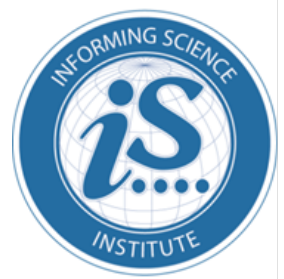

Proceedings of the Informing Science + Information Technology Education Conference

An Official Publication

of the Informing Science Institute

InformingScience.org

InformingScience.org/Publications

June 30 - July 4, 2019, Jerusalem, Israel

\title{
THE IMPACT OF CONTRIBUTION IN AID OF CONSTRUCTION ON UTILITY DILAPIDATED INFRASTRUCTURE: EVIDENCE FROM THE STATE OF FLORIDA [ABSTRACT]
}

\begin{tabular}{llr}
\hline Daniel Acheampong* & $\begin{array}{l}\text { Muma College of Business, } \\
\text { University of South Florida, Tampa, }\end{array}$ & dacheamp@mail.USF.edu \\
& FL, USA & \\
Tanya S. Benford & Lutgert College of Business & tbenford@,fgcu.edu \\
& Florida Gulf Coast University, USA & \\
Carlos Ramos & Muma College of Business, & cgramos1@mail.usf.edu \\
& University of South Florida, Tampa, & \\
& FL, USA
\end{tabular}

*Corresponding author

\begin{abstract}
Aim/Purpose The study examines the current credit treatment of Contribution in Aid of Construction (CIAC) on investor own utilities (IOU) and its impacts on the current state of utility infrastructure in the state of Florida.

Background

The Congressional Budget Office describes a synergist contributing to the present aged utility infrastructure is the cost of replacement within the water industry. The state of Florida treats Contribution in Aid of Construction (CIAC) as a liability with a credit expense balance. The ratemaking process does not include CIAC.

Methodology The study used the latent change/growth structural equation model with an observed sample of 80 selected utilities. The selected utilities generated 700 observations from the financial statements. We identified and build ratios from the NRRI and Acheampong et al. utility viability model and used VIF to address multicollinearity issues and linked test to specify the inclusion of the ratios. Ten ratios were used as the explanatory variables to current total assets of IOUs.
\end{abstract}

by Executive Review by Editor: Eli Cohen | Received: June 8, 2019 | Accepted: June 9, 2019.

Cite as: Acheampong, D., Benford, T. A., \& Ramos, C.. (2019). The impact of contribution in aid of construction on utility dilapidated infrastructure: Evidence from the state of Florida. Proceedings of the Informing Science and Information Technology Education Conference, Jerusalem, Israel, pp. 515-517. Santa Rosa, CA: Informing Science Institute. https://doi.org/10.28945/4371

(CC BY-NC 4.0) This article is licensed to you under a Creative Commons Attribution-NonCommercial 4.0 International License. When you copy and redistribute this paper in full or in part, you need to provide proper attribution to it to ensure that others can later locate this work (and to ensure that others do not accuse you of plagiarism). You may (and we encourage you to) adapt, remix, transform, and build upon the material for any non-commercial purposes. This license does not permit you to use this material for commercial purposes. 
Contribution

Findings

Recommendations for Practitioners

Recommendations for Researchers

Future Research

Keywords
The results may urge regulators to consider the current treatment of CIAC.

The study suggests a debit treatment of the CIAC amortization expenses and the recovered amount kept in a reserved account to replace the utility infrastructure, a trend analysis comparing the credit treatment and the debit treatment to determine the impact of CIAC on the current credit treatment.

The study complements the work completed by the study committee form by Florida House Bill No. 1389-2012, one of the findings for the committee was to establish a reserve fund for IOUs. However, they did not identify how to fund the reserve account to use to replace aged infrastructure. The results of the will enhance both practitioners and regulators understanding of the need to either maintain the current treatment of CIAC or make a policy change for CIAC to be treated with a debit balance. Both Regulators and practitioners will connect the relationship between CIAC and the total assets of utilities and find alternative means to enhance or improve the aged infrastructure within the water and wastewater industry.

AICPA in 2017 attempted to research into the treatment of CIAC among power and utility entities but focused on revenue recognition (FASB 606), and concluded FASB pronouncement does not address the treatment of CAIC; the study will be the first in-depth inquiry into the recognition of the of CIAC on improving the total assets of water and wastewater utilities. The study will further generate academic discussion on the inconsistent application by various states across the US on the applicability of CIAC. Should regulators or the NRRI pursue a debit or credit treatment consistently across the US and should FASB enact a pronouncement enhancing the principle-based of the method of CIAC?

The study focused on the alternative treatment of CIAC and its relationship with improving total assets of aged infrastructure among water and wastewater utility. The Regulation of the water and wastewater utilities are state-specific, and the various commissions differ in several policies for the industry. The treatment of CIAC as a debit balance study is an opening-door for further research into the donated capital treatment among the various states. We recommend a study comparing states treating CIAC as a debit balance to states treating it as a credit balance and its impact on utility viability and also plant asset improvement.

Contribution in Aid of Construction (CIAC), debit treatment, investor own utilities, dilapidated infrastructure, financial resources, credit treatment

\section{BIOGRAPHIES}

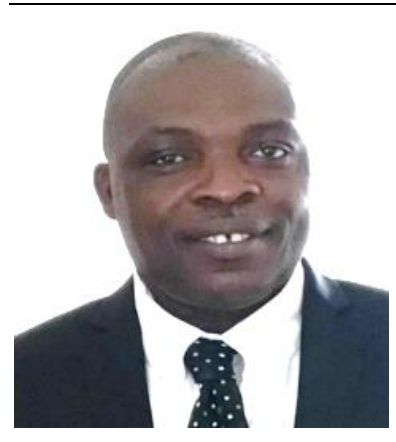

Daniel Acheampong joined the FGCU faculty in June 2011, as Accounting Instructor. He received his doctorate in accounting from the Argosy University in 2013. Dr. Acheampong is a current DBA student at University of South Florida Muma Business of College and a current reviewing partner with Daga Accounting Solutions. Prior to joining FGCU, he served as a utility auditor for the state of Florida (PSC) and founded Daga Accounting Solutions. His research work is published in the Journal of Finance and Accountancy and Accounting \& Taxation. email: dacheamp@mail.usf.edu. 


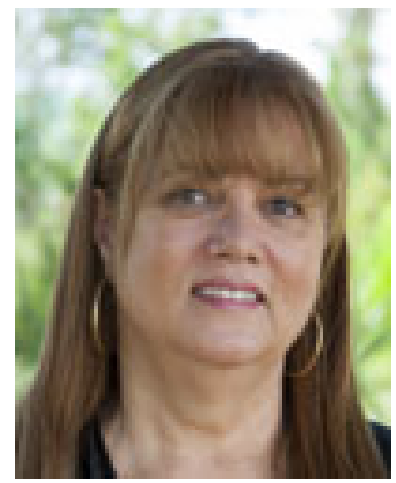

Tanya Benford, Department Chair of Accounting and Associate Professor at Florida Gulf Coast University, received a Ph.D. in Accounting with Information Systems as a supporting area of interest from the University of South Florida (2000). Tanya teaches Accounting Information Systems, has published numerous refereed journal articles, and has successfully competed for both internal and external research grant funding. Her research interests include business process controls and corporate governance as well as the impact of information technology on judgment and decision-making in accounting. Prior to entering academia, she was Director of Finance for the Atlanta Symphony Orchestra. She also has held senior management positions in both the airline and insurance industries and began her career as a staff accountant at Coopers \& Lybrand (PwC) in Miami, Fl. Email: tbenford@,fgcu.edu

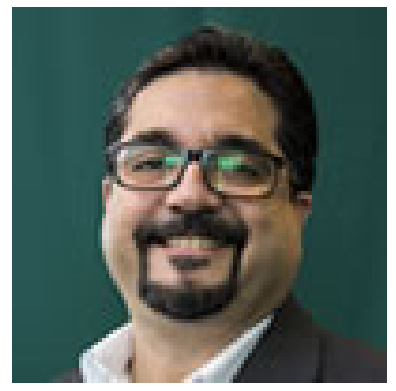

Carlos G Ramos is an Associate Vice President for the corporate accounting department with Marriott Vacations Worldwide with over 15 years of specialized experience in international accounting and crossborder taxation, mainly within Latin America. During his career as a professional practitioner, he has worked to establish operations within new global markets, focusing on international accounting issues and international taxation. This expertise allowed him to lead the design and implementation of a legal structure that facilitated cross-border investments that maximized tax efficiencies. Mr. Carlos G Ramos is a current DBA student at the University of South Florida Muma College of Business. email: cgramos1@mail.usf.edu 